\title{
Continuity or Liquidation in Situations of Ambiguity: Fuzzy Binomial Model to Valuate Leveraged Firms
}

\author{
Gastón S. Milanesi ${ }^{1, *}$, Emilio El Alabi ${ }^{1} \&$ Gabriela Pesce ${ }^{1}$ \\ ${ }^{1}$ Business Administration Department, Universidad Nacional del Sur., San Andrés 800, \\ Campus Altos de Palihue, Depto Ciencias de la Administración, UNS, Bahía Blanca (8000), \\ Provincia de Buenos Aires, Argentina \\ *Corresponding author: Business Administration Department, Universidad Nacional del Sur. \\ San Andrés 800, Campus Altos de Palihue, Depto Ciencias de la Administración, UNS, Bahía \\ Blanca (8000), Provincia de Buenos Aires, Argentina. E-mail: milanesi@uns.edu.ar
}

Received: November 6, 2014 Accepted: December 21, 2014 Published: March 25, 2015

doi:10.5296/rae.v7i1.6578 URL: http://dx.doi.org/10.5296/rae.v7i1.6578

\begin{abstract}
This paper proposes a fuzzy binomial valuation model to estimate leveraged firm value while conditioning its continuity or liquidation in cash flow generation after taxes to attend debt payments. It includes two triangular fuzzy variables. Thus, we incorporate ambiguity in the firm valuation process characterized by uncertainty in projections of both growth and financial costs. Our proposed model is presented, developed, and exemplified through a case which results complement both the DCF (under the adjusted present value) and the traditional real option binomial method. This occurs because, in one hand, DCF method assumes decisions' irreversibility and operating firms' situation. On the other hand, traditional binomial model weakens previous restrictions but does not incorporate ambiguous variables in the analysis. Hence, fuzzy logic applied to option models allows us to complement probabilistic valuation approach working on a frame of possibilities.
\end{abstract}

Keywords: firm valuation, fuzzy sets, binomial model, uncertainty, adjust present value, debt effects 


\section{Introduction}

The first explicit reference to intrinsic or theoretical value of a stock belongs to Williams (1938). He defines a stock value as its future dividends' present value. Also, this author sets premises related to financial projections, and a first classification of growth and value ${ }^{1}$ firms. Model formalization and popularization belongs to Durand (1957) and Gordon (1962) originating the well-known dividend discount valuation model (DDM) (Durand, 1957; Gordon 1962$)^{2}$. From fundamentals related to DDM, and as a variation to include it in firm valuation, arises the discounted cash flow model (DCF) (Pratt \& Grabowsky, 2008) ${ }^{3}$ including families of different firm's valuation methods. This is one of the most used valuation methods (Fornero, 2011). Its original formulation allows different treatments 4 related to capital structure in order to estimate firm value (Booth, 2007) through positive and negative cash flows associated to financial leverage (for instance, tax shields, emission costs, and dissolution costs weighted by its probability of occurrence). Without considering potential benefits of taking debt, this action adds financial risk having a negative impact in the theorical firm value in situations where costs are higher than benefits of leveraging. One of the main negative consequences of financial leverage is insolvency and following liquidation. Classic DCF, while keeping its leverage level constant, does present a weakness. It does not include contingent states of continuation and liquidation. This situation arises from traditional static valuation methods, and it overvalues a leveraged operating firm.

This weakness in DCF is healed through analytic tools of a dynamic valuation model, projecting different scenarios, and using real options theory (Broadle \& Kaya, 2007; Milanesi, 2014b). Motivated by these papers previously mentioned, we propose a model which is an alternative to the net present value (NPV). It includes contingent situations of sufficiency-insufficiency free cash flow in order to pay $\operatorname{debt}^{5}$, and uncertainty-ambiguity through the usage of fuzzy sets (Dubois \& Prade, 1980; Zadeh, 1965).

Our model assumes that random variables such as asset value, operating earnings, and liabilities' financial cost are adapted from classic binomial model (Cox \& Ross, 1976; Cox, Ross \& Rubinstein, 1979; Jarrow \& Rudd, 1982; Rendleman \& Bartter, 1979) to fuzzy logic

\footnotetext{
${ }^{1}$ We group as value firms those which MV/BV (market value to book value) ratio is less than one, and they, generally, have higher PERs (price-earnings ratio). We group as growth firms those which MV/BV ratio is higher than one and lower PERs. This classification is usually used in stock portfolios.

2 Traditional dividend discount model has suffered variations in growth progression (arithmetic-geometric), growth stages (one stage-multiple stages), expected dividend flow behavior (deterministic-stochastic) (Hurley \& Fabozzi, 1998; Hurley \& Johnson, 1998; Hurley, 2013).

${ }^{3}$ Firm valuation models could be classified in: a) Valuation by multiples and comparables where we could identify the price-earnings ratio (PER); market value-book value (MV/BV) ratio, Tobin's Q ratio, among other ratios. b) Cash flow valuation including dividend discount model (with its stochastic and deterministic variants) and discounted cash flow (capital cash flow, adjusted net present value, and weighted average cost of capital). c) Models based on economic benefit such as residual income and economic value added. d) Real options (Fernandez, 2012).

${ }^{4}$ Discounted cash flow could be classified in three big subgroups: (a) Weighted average cost of capital (wacc): firm value is obtained by free cash flow at wacc rate. It incorporates tax shield effects. (b) Adjusted net present value: firm value is obtained by adding unleveraged firm value and net tax shield. (c) Capital cash flow: Firm value is a result of discounted capital cash flow at the required rate of equity return.

${ }^{5}$ The financing decision conditions the estimated value of firm assets and equity to the stochastic generation of free cash flow to attend payments originated by debt. The preceding idea is consistent with thinking of firm's equity as a call option in the shareholder's favor (Black \& Scholes, 1973) assuming two different scenarios: (a) free cash flow is higher than debt payments which, as a consequence, assures firm continuity. (b) Free cash flow is lower than debt payments which derives in automatic firm liquidation and liabilities' cancelation with available assets.
} 
(Calle Fernández \& Tamayo Bustamante, 2011; Milanesi, 2013; Milanesi, 2014a; Muzzioli \& Torricelli, 2004; Zdnek, 2010). We assume the existence of two market deterministic imperfections related to financial decisions with an impact in firm value: earnings corporative taxes and liquidation costs.

We must highlight that, even though there exists rich literature ${ }^{6}$ on decisions' effects on capital structure, they are beyond the scope of this work. This paper's structure follows: first, we introduce some concepts, relations, and differences associated to probabilistic models and fuzzy binomial real option models. Second, we expose a set of equations used to estimate an operating firm value, adjusting its value as a consequence of ambiguity of possible solvency-insolvency status, and positive and negative impacts of financial leverage (tax shields and break costs). In order to clarify it, we illustrate its functioning on an investment project of an oil exploitation concession. We compare the obtained value with the adjusted present value and the traditional binomial model. Finally, we present our main conclusions.

\section{Binomial probability and fuzzy model}

\subsection{Binomial probability model}

The binomial model is developed in a risk neutral environment. This means that it is able to value options in terms of expected cash flows discounted from expiration date to present assuming they grow at a risk free rate. As a consequence, underlying asset's rate does not affect derivative value, but its volatility associated to underlying's returns does affect option value $^{7}$. Risk neutral valuation in options requires the existence of perfect correlation between changes in option value and underlying asset since changes in underlying asset is the only risk variable for the derivative. For instance, a balanced portfolio with a long position in options and a short position in the underlying asset should not have any random fluctuation since variations in stock price (short position) should be balanced by variations in the option. The result of the previous strategy is the rate of return of a risk free asset. The main key to build this portfolio is to determine the amount of stock that we are going to sell short ${ }^{8}$. This quantity is known as "delta," and it is estimated by a financial model".

\footnotetext{
${ }^{6}$ From seminal Works (Modigliani \& Miller, 1958; Modigliani \& Miller 1963), vast research has been developed trying to explain capital structure decisions effects on firm's value. Different works have advanced over assumptions' compatibilities and the CAPM (Capital Asset Pricing Model) approach (Rubinstein, 1973). They did not affect classical assumptions over capital structure and value firm. However, studies over on information asymmetry go over these assumptions. They could be classified as those which study information asymmetry before and after contract. Before constitutive contract, we could identify: (1) signaling: (a) debt signaling roll (Ross, 1977), (b) financial hierarchy (Leland \& Pyle, 1977; Myers \& Majluf, 1984) and (2) detection (Stiglitz \& Weiss, 1981). After contract: (1) Agency problems; some of their models: (a) agency costs in stock and debt (Jensen \& Meckling, 1976); (b) agency costs in free cash flow (Jensen, 1986); (c) stakeholder coinvestment theory (Titman, 1984) and (2) firm lifecycle approach (Berger \& Udell, 1998). At the same time, we could cite studies on corporative strategy theory and its effects on financial decisions (Brander \& Lewis, 1986). There are works that summarize different theories on capital structure, information asymmetry and agency costs (Copeland, Weston \& Shastri, 2004).

${ }^{7}$ In real world, it is more complex to estimate growth rate than volatility (Wilmott, 2009).

${ }^{8}$ Selling short is known as a leverage operation where we borrow stocks that are sold to be ourselves liquid with the obligation to return those stocks at the agreed date.

${ }^{9}$ Eliminating total risk theorically is an ideal hard to apply in real life since we usually need a mathematical model to calculate Greek letter Delta, and financial models are approached but not exact replicas of complex reality. Main limitations in risk neutral valuation are: (a) It is required to continuously balance our hedging since Delta varies continuously (not
} 
Risk neutral valuation allows us to value derivatives by projecting or simulating a risk neutral path for the underlying in order to calculate the option's cash flow. These are discounted by backward induction until the date that we intend to value it. Finally, we get its average and obtain its intrinsic value. Therefore, the average expected discounted cash flow of the option is the theoretical value of the option.

In real option valuation using binomial model in a risk neutral environment, it is required to estimate the up $(u)$ and down $(d)$ coefficients. These parameters are the basis in order to derive the certain equivalent coefficients and the binomial grill (firm value and operating cash flows). They are quantified from price volatility $(\sigma)$ associated to a financial portfolio which is a twin or replica of the underlying cash flow. We assume the asset follows a Brownian geometric stochastic process modeled in discrete time. Equations related to coefficients and the underlying's random path in the binomial grill are:

$u=e^{(\sigma \times \sqrt{t})}$

$d=e^{(-\sigma \times \sqrt{t})}$

$V_{t}=\left[V_{t-1} \times u ; V_{t-1} \times d\right]$

The project expanded value at expiration is the maximum value between the underlying asset minus the exercise price $(X), V_{t}=\max \left(V_{t}-X ; 0\right)$ for real options which are similar to financial calls, and $V_{t}=\max \left(X-V_{t} ; 0\right)$ for real options which are similar to financial puts. The project intrinsic value is determined by backward induction using certain equivalent coefficients $\left(p_{u} ; p_{d}\right)$. The coefficients and their present values are calculated with the following expressions:

$p_{u}=\frac{(1+r f)-d}{u-d}(4)$
$p_{d}=1-p_{u}$
$V_{t}=\left[V_{i(t+1)} \times p_{u}+V_{j(t+1)} \times p_{d}\right] \times e^{-r f}$

Where $(r f)$ represents the risk free rate of time value of money, and $V_{i(t+1)} ; V_{j(t+1)}$ represents the expanded value in immediate posterior nodes.

Present volatility is defined by the $\sigma$ parameter in Black-Scholes (B-S) differential partial equation (Black \& Scholes, 1972; Black \& Scholes, 1973). This is one of the main inputs of the B-S and binomial models. It is impossible to obtain this parameter by direct observation. Therefore, it must be calculated using statistical models. There are different types of volatilities depending on the moment in time where data is got: (a) historic volatility is obtained from observations in the underlying asset prices; (b) implicit volatility is the number in BMS formula that makes the theoretical price and the actual market price equal; (c)

discretely). Therefore, we must sell-buy stocks in order to keep our risk free position; (b) It is required to follow certain assumptions associated to asset stochastic process (following a Brownian geometric process, without any jumps, and with known and finite volatility). 
hedging volatility is the parameter that we introduce in the Greek letter delta in order to calculate the units of underlying to sell short with the purpose of being covered (Wilmott, 2009).

In real options models, these three volatility types are useful as an input for valuation models, where it is necessary a financial asset or portfolio correlated to the project cash flow. In order for this to occurred, markets must by complete which is one of the basic assumptions and main weakness of real options theory (Wang \& Halal, 2010). A solution to not having a replica financial asset and incomplete markets is brought by the marketed asset disclaimer (MAD) (Copeland \& Antikarov, 2001; Copeland \& Tufano, 2004) ${ }^{10}$. In those situations where markets are incomplete, and data is vague or ambiguous (for instance, investments in undeveloped environments, investments' valuation in real and innovative assets, investments in startups or closed firms without comparable firms), options valuation models which use a fuzzy logic are a complement and an alternative to be considered. In particular, we could consider binomial fuzzy model as a complement of its probabilistic traditional model.

\subsection{Fuzzy Binomial Model}

Fuzzy logic applied to option models allows us to complement probabilistic valuation approach working on a possibility frame. It enhances simulation and scenarios technique capturing positive bias in the possible investment distribution. This is a characteristic for real options contained in the asset (potential benefit value limiting risk on potential losses).

As in probabilistic binomial model, it is necessary to estimate up and down coefficients, with triangular fuzzy numbers in this case, resulting in an area of possible outcomes (equations 7 and 8).

$$
\begin{aligned}
& u^{\prime}=\left[u_{1}, u_{2}, u_{3}\right]=\left[e^{(((1-V C) \times \sigma) \times \sqrt{t})}, e^{(\sigma \times \sqrt{t})}, e^{(((1+V C) \times \sigma) \times \sqrt{t})}\right](7) \\
& d^{\prime}=\left[d_{1}, d_{2}, d_{3}\right]=\left[\frac{1}{u_{1}}, \frac{1}{u_{2}}, \frac{1}{u_{3}}\right]
\end{aligned}
$$

Extreme values are $u^{\prime}=\left[u_{1}, u_{2}, u_{3}\right]$ (up) and $d^{\prime}=\left[d_{1}, d_{2}, d_{3}\right]$ (down). Represented scenarios are: $u_{1}$; $d_{3}$ least movement wideness, $u_{3} ; d_{1}$ most movement wideness, and $u_{2} ; d_{2}$ base case. These are calculated utilizing a variation coefficient (VC), as a measurement of possible interval from maximum to minimum value for volatility $(\sigma)$ (Liao \& Ho, 2010). This is assumed based on experts' opinions and judgments. If we do not find a replica financial asset, volatility could be obtained applying the MAD approach as it was explained previously.

Because of the positive bias in the triangular possibility distribution, the up factor generates a higher value than the down factor. This down factor reverts them back to zero and, the base

\footnotetext{
10 This approach assumes the market Price that the project will be negotiated is its net present value. Thus, its volatility $(\sigma)$ is inferred as following (Smith, 2005):

(a) Project's cash flows are submitted to Monte Carlo simulation. For each iteration, we obtain a rate of return (z) as a result of the logarithm of dividing net present value in year 1 and net present value in year $0 \mathrm{z}=\ln \left(V A N_{1} / V A N_{0}-1\right)$.

(b) By iteration, simulation throws a sample of values as a result $\left(z_{i}\right)$. From this, we obtain mean return $\left.\bar{z}=E(z)\right)$ and its standard deviation $(s)$ associated to moments 0 and 1.

(c) Project volatility is equal to $(\sigma)=S / \sqrt{\Delta t}$. If time interval in which cash flows are expressed is equal to 1 , then $(\sigma)=s$.
} 
case, returns the same result as the obtained by the binomial model. Having these three results (up-medium-down), a triangular fuzzy number is generated on each node of the binomial grill (Equation 9).

$V_{t}^{\prime}=\left[V_{t-1}^{\prime} \times u^{\prime} ; V_{t-1}^{\prime} \times d^{\prime}\right]$

As in the binomial model, the project's expanded fuzzy value at expiration is the maximum between the underlying fuzzy asset value minus the exercise price $(X)$ and zero, $V E^{\prime}{ }_{t}=$ $\max \left(V_{t}^{\prime}{ }_{t}-X ; 0\right)$ for real options that are similar to financial calls. Also, it is $V E^{\prime}{ }_{t}=$ $\max \left(X-V_{t}^{\prime} ; 0\right)$ for real options that are similar to financial puts. Project's intrinsic value is determined by backward induction using fuzzy certain equivalent coefficients $\left(p_{u}^{\prime} ; p^{\prime} d\right)$.

$p_{u}^{\prime}=\frac{(1+r)-d^{\prime}}{u^{\prime}-d^{\prime}}(10)$

$p_{d}^{\prime}=1-p_{u}^{\prime}$

Fuzzy binomial model creates a possibility distribution on each node that maximizes and minimizes the possible values' area related to the underlying real asset. The couple of certain equivalent coefficients to be used in the backward induction process are combined in the following manner (Liao \& Ho, 2010): (a) the minimum wideness scenario combines the fuzzy certain equivalent coefficients of up and down with minimum value; (b) the maximum wideness scenario combines the fuzzy certain equivalent coefficients of up and down with maximum value ${ }^{11}$. The base case is solved as it would be solved in a traditional binomial model. Assuming a triangular fuzzy number, with up coefficient $u=(1$ lowest, 2 base, 3 highest), couples of fuzzy certain equivalent coefficients used in the backward induction process are set in the following manner:

$p_{u}^{\prime}, p_{d}^{\prime}=\left[\left(p_{u 3}^{\prime}, p_{d 1}^{\prime}\right) ;\left(p_{u 2}^{\prime}, p_{d 2}^{\prime}\right) ;\left(p_{u 1}^{\prime}, p_{d 3}^{\prime}\right)\right]$

The positive bias related to the fuzzy number (option value) is captured regrouping the pairs of certain equivalent coefficient (equation 12). Therefore, the minimum (maximum) weight associated to least (most) wideness values. Then, the certain equivalent coefficient comes up from dividing growth rate without risk minus the down factor (numerator) and the up factor minus de up factor (denominator). Assuming risk free rate is constant, variation is determined by the up and down factors. The certain equivalent coefficient obtained out if the most (least) wideness movement presents a lower (higher) numerator and higher (lower) denominator. Thus, it is used in the up weighting for the least (most) wideness, and its complement is used in the down with the least (most) wideness. So, $u_{3}^{\prime}>u_{2}^{\prime}>u_{1}^{\prime} \rightarrow d^{\prime}{ }_{3}<d_{2}^{\prime}<d^{\prime}{ }_{1} \rightarrow$ $p^{\prime}{ }_{3}<p^{\prime}{ }_{2}<p^{\prime}{ }_{1} \rightarrow \llbracket\left(1-p^{\prime} \rrbracket_{3}\right)>\left(1-p^{\prime}{ }_{2}\right)>\left(1-p^{\prime}{ }_{1}\right)$.

\footnotetext{
${ }^{11}$ Real option value is a direct function of volatility. Up and down coefficients are a direct function with it. Therefore, the higher is the wideness of movements, the higher option value, and viceversa. This drives us to assume optimistic (pessimistic) scenarios associated to the project that are related to volatility connected to higher (lower) base case and, also, movements connected to the base case with higher (lower) wideness.
} 


\section{IIMacrothink}

Expanded intrinsic value is determined by backward induction through the following expression:

$V_{t}^{\prime}=\left[V_{i(t+1)}^{\prime} \times p^{\prime} u+V_{j(t+1)}^{\prime} \times p_{d}^{\prime}\right] \times e^{-r f}$

Central value calculation related to the fuzzy number is altered by the right bias that has the project's possible outcome distribution (Carlsson \& Fuller, 2001). Assuming $V E^{\prime}=$ $\left[\operatorname{VE}_{1}(\alpha) ; \operatorname{VE}_{3}(\alpha)\right]$ is a fuzzy number and $\lambda \in[0,1]$, the fuzzy net present value (VANEB), $E(V E)^{\prime}$ is defined as:

$E\left(V^{\prime}\right)=\int_{0}^{1}\left[(1-\lambda) V_{1}(\alpha)+\lambda V_{3}(\alpha)\right] d \alpha(14)$

Where $\lambda$ represents the "pessimism-optimism" weighted index (Yoshida, Yasuda, Nakagami $\&$ Kurano, 2006) estimated by the following equation:

$\lambda=\frac{A D}{A I+A D}$

Having estimated the index, we substitute it on equation 15, and we obtain the fuzzy expected net present value of the option (equation 16):

$E\left(V^{\prime}\right)=\frac{\left[(1-\lambda) V_{1}+V_{2}+\lambda V_{3}\right]}{2}$

\section{Firm valuation through a fuzzy binomial numerical model: Debt impact in project value and solvency-insolvency status}

The proposed numerical model is developed from the fuzzy binomial model. It incorporates a company's growth rate $(a)$ that comes out of the difference between the risk free rate $(r)$ and the payments rate $(q)$ :

$a=e^{(r-q) \Delta t}$

Finally, fuzzy risk neutral coefficients are obtained through the following expression:

$p_{u}^{\prime}=\frac{a-d^{\prime}}{u^{\prime}-d^{\prime}}$

Coefficients $\mathrm{u}^{\prime}, \mathrm{d}^{\prime}, \mathrm{p}_{\mathrm{u}}^{\prime}, \mathrm{p}_{\mathrm{d}}^{\prime}$ are obtained through equations 10, 11, and 12. Once we define the fuzzy binomial model basic parameters, we proceed to a numerical setting. 


\subsection{Fuzzy binomial grill to estimate firm value through cash flows}

3.1.1 Fuzzy binomial grill to estimate an unleveraged firm value and its cash flow

Taking initial value of assets of an unleveraged firm $\left(V_{u}\right)^{12}$ as a starting point, we project our first fuzzy binomial grill applying equation 13. It is useful to build the grill related to firm fuzzy free cash flow $\left(\delta_{t}\right)$. On each node, fuzzy free cash flow is the product between firm value for a node (equation 13) and rate of return after taxes $\left(q=q_{a t} \times(1-\tau)\right)$, and the expression is $V_{i}^{\prime} \times q$. Alternatively, fuzzy cash flow could be estimated as the following expression:

$\delta^{\prime}{ }_{t}=V_{i}{ }_{i} e^{q \Delta t}-V^{\prime}{ }_{i}$

\subsubsection{Fuzzy binomial grill to estimate debt cash flow}

On each node, we must calculate debt cash flow. In order to do this, we assume that the firm issues bonds with fuzzy periodical payments $\left(C_{t}^{\prime}\right)$ that includes interests and principal cancelation $(P)$ at the end of the bonds lifetime. Principal value is deterministic while interests follow a fuzzy behavior assuming a rate $i^{\prime 13}$.

$C_{t}^{\prime}=i^{\prime} \times P(20)$

In a model that includes earnings taxes, debt cash flow is expressed as $(1-\tau) C_{t}{ }^{\prime}$ being $\tau$ the earnings tax rate, and $\Delta^{\prime} \tau=i^{\prime} \times \tau$, the fuzzy value related to tax shield.

\subsubsection{Fuzzy binomial grill to estimate equity cash flow}

Fuzzy equity cash flow is the difference between fuzzy free cash flow and fuzzy debt cash flow $\delta_{t}^{\prime}-C_{t}^{\prime}$. It represents the amount of cash flow for shareholders. Two different scenarios could be presented: (a) $\delta_{t}^{\prime}<C_{t}^{\prime}$ we proceed to debt cancelation and shareholders' equity liquidation; (b) $\delta_{t}^{\prime}>C_{t}^{\prime}$ continuity.

\subsection{Owners' capital, debt, and asset value from fuzzy binomial grill}

3.2.1 Non-conditioned valuation by insolvency or continuity scenarios using a fuzzy binomial grill

Through fuzzy binomial grill, we calculate unconditioned fuzzy values related to equity $\left(E^{\prime}\right)$, debt $\left(D^{\prime}\right)$, and operating assets $\left(F^{\prime}\right)$. Nodes values related to the last projected period associated to equity $\left(E^{\prime} T\right)$, comes out of adding the unleveraged firm value (equation 13) and free cash flow (equation 19) minus the debt cash flow (equation 20), for each respective node $E_{T,\left(u^{\prime}, d^{\prime}\right)}^{\prime}=V_{T,\left(u^{\prime}, d^{\prime}\right)}^{\prime}+\delta_{T,\left(u^{\prime}, d^{\prime}\right)}^{\prime}-C_{T,\left(u^{\prime}, d^{\prime}\right)}^{\prime}$. Recursively, we obtain unconditioned values for continuity-liquidation states through the following equations:

$$
\begin{aligned}
& E^{\prime}=e^{-r \Delta t}\left(p^{\prime} E_{u^{\prime}}^{\prime}+1-p^{\prime} E_{d^{\prime}}^{\prime}\right) \\
& D^{\prime}=e^{-r \Delta t}\left(p^{\prime} D_{u^{\prime}}^{\prime}+1-p^{\prime} D_{d^{\prime}}^{\prime}\right)
\end{aligned}
$$

\footnotetext{
12 Total operating assets independently of the firm's capital structure at time $t=0$.

${ }^{13}$ We assume a value $i$ and minimum and maximum extremes of $i-\alpha ; i+\beta$, respectively.
} 
$F^{\prime}=e^{-r \Delta t}\left(p^{\prime} F^{\prime} u^{\prime}+1-p^{\prime} F^{\prime} d^{\prime}\right)$

3.2.2 Conditioned valuation by insolvency or continuity scenarios using a fuzzy binomial grill

We will develop steps to estimate leveraged asset total value, debt, shareholders' equity conditioned to generating cash flow on each projected fuzzy scenario. There are two contingent states that condition projected fuzzy nodes ${ }^{14}$ : (1) $\delta_{t}^{\prime}>C_{t}^{\prime}$ continuity with best repayment, and (2) $\delta_{t}^{\prime}<C_{t}^{\prime}$ insufficient funds proceeding to liabilities cancelation and equity liquidation. In order to accomplish this, we must segregate total projection period in three moments: (a) final horizon grill projection (T), (b) intermediate nodes $(0<t<T)$, and (c) initial moment $(t=1 \rightarrow 0)$.

(a) Equation set to estimate conditioned values at final horizon(T)

a.1) Firm continuity (T): Fuzzy firm value plus fuzzy free cash flow is equal or higher to debt payment (fuzzy interest plus equity). The conditioning expression is $V^{\prime}{ }_{T}+\delta_{T}^{\prime} \geq(1-$ $\tau) C_{t}^{\prime}+P$. The following is the equation set:

$E_{T}^{\prime}=V_{T}^{\prime}+\delta_{T}^{\prime}-(1-\tau) C_{t}^{\prime}-P$

$D_{T}^{\prime}=C_{t}^{\prime}+P$

$F_{T}^{\prime}=V_{T}^{\prime}+\delta_{T}^{\prime}+\Delta^{\prime} t$

a.2) Liquidation (T): Fuzzy firm value plus fuzzy free cash flow is insufficient for debt payment (fuzzy interest plus equity). The conditioning expression is $V_{T}^{\prime}+\delta_{T}^{\prime}<(1-$ $\tau) C^{\prime} \Delta^{\prime} t+P$. On this case, transaction costs associated to liquidation are represented by $\alpha$. The following is the equation set:

$E_{T}^{\prime}=0$ (27)

$D^{\prime}{ }_{T}=(1-\alpha)\left(V^{\prime}{ }_{T}+\delta^{\prime}{ }_{T}\right)(28)$

$F_{T}^{\prime}=(1-\alpha)\left(V_{T}^{\prime}+\delta_{T}^{\prime}\right)$

(b) Equation set to estimate conditioned intermediate nodes values $(t<T ; t>0)$

In order to estimate solvency and insolvency status, we take, as a starting point, fuzzy shareholders' equity unconditioned to the solvency or insolvency event in funds' generation (equation 21). It is denoted as $\widetilde{E^{\prime}}=e^{-r \Delta t}\left(p^{\prime} E_{u^{\prime}}^{\prime}+1-p^{\prime} E_{d^{\prime}}^{\prime}\right)$. Possible scenarios are:

b.1) Firm continuity $(t<T ; t \geq 1)$ : There is no liquidation risk if fuzzy free cash flow plus fuzzy equity's net present value is sufficient to take care of fuzzy debt cash flow. The conditioning expression is $\widetilde{E}_{t}^{\prime}+\delta_{t}^{\prime} \geq(1-\tau) C^{\prime} \Delta^{\prime} t$. The following is the equation set to value intermediate nodes:

$E_{t}^{\prime}={\widetilde{E^{\prime}}}_{t}^{\prime}+\delta_{t}^{\prime}-(1-\tau) C_{t}^{\prime}(30)$ ${ }_{14}$ Considering liquidation-continuity contingent states over fuzzy posterior nodes, fuzzy preceding nodes' values are
conditioned by the contingent states previously mentioned. 
$D_{t}^{\prime}=C_{t}^{\prime}+e^{-r \Delta t}\left(p^{\prime} D_{u^{\prime}}^{\prime}+1-p^{\prime} D_{d^{\prime}}\right)(31)$

$F^{\prime}{ }_{t}=\delta_{t}^{\prime}+\Delta^{\prime} t+e^{-r \Delta t}\left(p^{\prime} F_{u^{\prime}}^{\prime}+1-p^{\prime} F_{d^{\prime}}\right)$

b.2) Liquidation $(t<T ; t>0)$ : Firm liquidation occurs if the addition of fuzzy free cash flow and fuzzy equity's net present value is insufficient to take care of fuzzy debt cash flow. The conditioning expression is ${\widetilde{E^{\prime}}}_{t}^{\prime}+\delta^{\prime}{ }_{t}<(1-\tau) C^{\prime} \Delta^{\prime} t$. The following is the equation set:

$E_{t}^{\prime}=0$

$D^{\prime}{ }_{t}=(1-\alpha)\left(V_{t}^{\prime}+\delta^{\prime}{ }_{t}\right)$

$F^{\prime}{ }_{t}=(1-\alpha)\left(V^{\prime}{ }_{t}+\delta^{\prime}{ }_{t}\right)$

(c) Equation set to estimate conditioned initial value $(t=1 \rightarrow 0)$

Finally, we are able to obtain present value in $t=0$ once we calculate final values $(T,(a))$ and intermediate values $(t<T ; t>,(b))$ conditioned by (continuity-liquidation) scenarios in fuzzy nodes. In this case, we must estimate initial values recursively from time period $t=1$ to $t=0$; $(t=1 \rightarrow 0)$. The following is the equation set:

$$
\begin{aligned}
& E_{0}^{\prime}=e^{-r t}\left(p^{\prime}\left(E_{u^{\prime}}^{\prime}+\delta_{t u^{\prime}}^{\prime}-(1-\tau) C_{t}^{\prime}\right)+1-p^{\prime}\left(E_{d^{\prime}}^{\prime}+\delta_{t d^{\prime}}^{\prime}-(1-\tau) C_{t}^{\prime}\right)\right) \\
& D_{0}^{\prime}=e^{-r \Delta t}\left(p^{\prime} D_{u^{\prime}}^{\prime}+1-p^{\prime} D_{d^{\prime}}^{\prime}\right)-\Delta^{\prime} t \\
& F_{0}^{\prime}=e^{-r \Delta t}\left(p^{\prime}\left(F_{u^{\prime}}^{\prime}+\delta_{t u^{\prime}}^{\prime}\right)+1-p^{\prime}\left(F_{d^{\prime}}^{\prime}+\delta_{t d^{\prime}}^{\prime}\right)\right)
\end{aligned}
$$

Values $E^{\prime}{ }_{0}, D^{\prime}{ }_{0}, F^{\prime}{ }_{0}$ are fuzzy expressions associated to minimum, maximum and most possible values related to the fuzzy triangular number. Mean fuzzy expected value is obtained through equations 14,15 , and 16 .

\section{Applying binomial numerical model, insolvency possibility, and variable sensibility analysis}

We will proceed to illustrate model functioning using an investment project about oil exploitation. This case was originally described by Smith (2005). We pretend to determine an investment project value of a concession contract to exploit an oil field for a three-year period. Technical and feasibility studies show that total reserves are 100 millions barrels of oil, and by $\mathrm{t}=0$ we are planning to produce ten more millions of barrels. We estimate: (a) production decreasing at $15 \%$ annual rate after year 1 ; (b) price of barrel of crude oil increasing at $3 \%$ annually; (c) exploitation costs increasing at $\%$ annually; and (d) stable fixed costs (there is not changes in structure). While projecting free cash flows, we apply to following variables: (a) Projected crude oil price per barrel is equal to $\$ 100$, where production costs represent $80 \%$ of selling price; (b) fixed costs for ten millions. Project is financed with a capital structure of $70 \%$ debt and 30\% shareholders' equity. These magnitudes are determined over the unleveraged project $(V u)$. It is defined using the adjusted present value (APV) model as a variant to the discounted cash flow, using the following expression: 
$V_{l}=V_{u}+E D$

In the previous equation, APV or leveraged firm value $(V l)$ is equal to adding unleveraged firm value $(V u)$ and the effects of debt $(E D)$. In this case, we consider only the effects of tax shield produced by interests where the tax rate is $35 \%$. We estimate $\mathrm{Vu}$ with the following expression:

$V_{u}=\sum_{t=1}^{n} \frac{F F L_{t}}{\left(1+k_{u}\right)^{t}}$

Here, $F F L_{t}$ represents project free cash flows and $k_{u}$ is the unleveraged cost of capital rate. Assuming that debt is risky $\left(\beta_{d} \neq 0\right)$, we use the following expression:

$\beta_{u}=\frac{\beta_{l}+\beta_{d} W_{d} / W e^{(1-t)}}{1+^{W_{d}} / W e^{(1-t)}}$

In order to estimate $k_{u}$, we apply CAPM. Unleveraged beta is estimated by subtracting effects of capital structure to leveraged beta. Capital structure is represented by $W_{d}$ (debt proportion) and $W_{e}$ (shareholders' equity proportion).

Debt effect comes out of tax shield as a result of borrowing, (txC). In this example, debt is structured with an American bond paying a 5\% annually over $70 \%$ of Vu, having its rescue of capital at the end of the third year.

On Table 1, we expose data associated to free cash flow projections, cash flows present value and unleveraged firm value (equation 40). Unleveraged firm value is equal to $\$ 455.40$ millions. On Table 2, we present used inputs to determine the required rate of return without debt, from equation 41 , which is equal to $10.92 \%{ }^{15}$.

\footnotetext{
${ }^{15}$ We assume that the Project generates cash flows perfectly correlated to oil price which is expressed in American dollars. Data was obtained from Aswath Damodaran website: http://pages.stern.nyu.edu/ adamodar/. Leveraged betas and capital structure by sector were obtained from the chart named "leveraged and unleveraged betas by sector." Additional market risk for Argentina was gotten from the chart called "country default spread and risk-premium for other markets." Finally, risk free rate is a 10-year T-bond with arithmetic mean 2004-2013 from the chart named "annual returns on stock, T-bond and T-bill: 1928 - Current."
} 


\section{Macrothink}

Research in Applied Economics

ISSN 1948-5433

2015, Vol. 7, No. 1

Table 1. Variable projections, free cash flow, and present value estimation of an unleveraged firm

\begin{tabular}{|c|c|c|c|c|c|c|c|c|}
\hline Projections & & $\mathbf{0}$ & & 1 & & 2 & & 3 \\
\hline Oil reserves (millions of barrels) & & 100.00 & & 90.00 & & 80.00 & & 71.50 \\
\hline Production level (millions of barrels) & & 10.00 & & 10.00 & & 8.50 & & 7.23 \\
\hline Operating variable cost rate (per barrel) & $\$$ & 80.00 & $\$$ & 81.60 & $\$$ & 83.23 & $\$$ & 84.90 \\
\hline Crude oil price (per barrel) & $\$$ & 100.00 & $\$$ & 103.00 & $\$$ & 106.09 & $\$$ & 109.27 \\
\hline Sales (millions) & & & $\$$ & $1,030.00$ & $\$$ & 901.8 & $\$$ & 789.5 \\
\hline Production costs (millions) & & & $\$$ & -816.00 & $\$$ & -707.5 & $\$$ & -613.4 \\
\hline Fixed costs (millions) & & & $\$$ & -10.00 & $\$$ & -10.0 & $\$$ & -10.0 \\
\hline Free cash flow after taxes (millions) & & & $\$$ & 204.00 & $\$$ & 184.3 & $\$$ & 166.1 \\
\hline Cash flow present value (PV@ku) & & & $\$$ & 183.91 & $\$$ & 149.78 & $\$$ & 121.71 \\
\hline $\begin{array}{l}\text { Unleveraged Project value Vu } \\
\text { (PV@ku) }\end{array}$ & $\$$ & 455.40 & & & & & & \\
\hline
\end{tabular}

Source: Own elaboration.

Table 2. Used variables to determine cost of capital rate without debt

\begin{tabular}{lc}
\hline \multicolumn{1}{c}{ Cost of Capital Rate } & Values \\
\hline Risk free rate (1). See note 16. & $4.69 \%$ \\
Market expected return (2). See note 16. & $14.75 \%$ \\
Comparable observed leveraged ß. See note 16 & 1.24 \\
Comparable firm capital structure (Wd/We). See note 16. & 1.54 \\
Project unleveraged B (3) (equation 41) & 0.61969015 \\
Project Ku (1)+((2)-(1))*(3) & $10.92 \%$
\end{tabular}

Source: A. Damodaran website http://pages.stern.nyu.edu/ adamodar/. Own elaboration.

Project initial value without debt $(V u)$ is $\$ 455.40$ millions. Nominal initial debt $(D)$ is $70 \%$ of this value. Consequently, debt rises to $\$ 318.78$ millions with a $5 \%$ coupon assuming cash flow model holds, and it does not condition firm value to the possibility of insolvency and liquidation.

The fuzzy binomial numerical model proposed allows us to estimate a conditioned value to the solvency-insolvency scenarios as a result of financial leverage. Input variables are exposed on Table 3: 
Table 3. Initial variables

\begin{tabular}{|c|c|c|}
\hline VO (firm without debt) & $\$$ & 455.40 \\
\hline$\sigma$ (cash flow deviation) & & $30 \%$ \\
\hline$q$ (cash flow rate of return) & & $5 \%$ \\
\hline$r$ (risk free rate) & & $6.00 \%$ \\
\hline$D$ (principal debt) & $\$$ & 318.78 \\
\hline$i$ (coupon debt rate) & & $5 \%$ \\
\hline$t$ (marginal tax rate) & & $35 \%$ \\
\hline$\alpha$ (liquidation costs) & & $1 \%$ \\
\hline
\end{tabular}

Source: Own elaboration.

Cash flow rate of return $(q)$ is $5 \%$ and leverage ratio $\mathrm{D} / \mathrm{V}$ is $70 \%$. Model ambiguity or uncertainty is explained in two variables: (a) project possible variables and cash flow for fuzzy nodes $\left(V_{i}^{\prime} ; \delta^{\prime}{ }_{t}\right)$, equations 13 and 19; (b) borrowing interest rate $(i)$, equation 20.

As we mentioned in 2.1, volatility is estimated applying MAD (Copeland \& Antikarov, 2001). The interval for the construction of a minimum maximum triangular fuzzy number is predicted with the variation coefficient (VC) (Liao \& Ho, 2010). We assume that volatility with a MAD approach is $30 \%$ and debt interest rate is $5 \%$ annually. The VC for volatility is $15 \%$ and for debt interest rate is $30 \%$ as we exposed on Table 4 :

Table 4. Volatility, interest, and TFN extremes

\begin{tabular}{ccccc}
\hline TFN Extremes $\left(\sigma^{\prime}, i^{\prime}\right)$ & Fuzzy $\sigma$ & $\mathrm{VC}(15 \%)$ & Fuzzy $i$ & $\mathrm{VC}(30)$ \\
$\mathrm{a}, \varepsilon(1)($ base $)$ & $\Sigma$ & $30.00 \%$ & $i$ & $5.00 \%$ \\
$\mathrm{a}-\alpha, \varepsilon(0)$ (negative extreme) & $(1-V C) *^{\circ}$ & $25.50 \%$ & $(1-V C) *_{i}$ & $3.50 \%$ \\
$\mathrm{a}+\beta, \varepsilon(0)$ (positive extreme) & $(1+V C) * \sigma$ & $34.50 \%$ & $(1+V C) *_{i}$ & $6.50 \%$ \\
\hline
\end{tabular}

Source: Own elaboration.

Preceding tables' values allow us to estimate up and down coefficients and fuzzy certain equivalents (equations 7, 8, 10, and 11). On the third section of Table 5, we expose pair of coefficients associated to each scenario (equation 12).

Variables in Tables 4 and 5 allow us to project grill to calculate conditioned value to solvency-insolvency scenarios as a result of financial risk of debt. Next, we will present the sequence for calculating it:

A) Binomial grill projection $V^{\prime}, \delta^{\prime}, C^{\prime}$ : For building it, we use equations 13, 19, and 20. On each node, we expose: firm value $\left(V_{;}^{\prime}\right)$ (first row), free cash flow out of taxes $\left(\delta^{\prime}\right)$ (second 
row), and debt payments without considering tax shields $\left(C^{\prime}\right)$ (third row). On gray, we highlight the traditional binomial model's outcome which is equal to the TFN value a, $\varepsilon(1)$; we set the minimum value to the superior extreme on each node; $a-\alpha, \varepsilon(0)$, and the maximum value to the inferior extreme; $\mathrm{a}+\beta, \varepsilon(0)$.

B) Unconditioned $\left(E^{\prime}\right),\left(D^{\prime}\right),\left(F^{\prime}\right)$ projection binomial grill: As a second step, we must project the fuzzy binomial grill to estimate unconditioned shareholders' equity $\left(E^{\prime}\right)$, debt $\left(D^{\prime}\right)$, and operating assets total value $\left(F^{\prime}\right)$ by the probability of firm insolvency on intermediate nodes (equations 21 to 23 ).

Table 5. Fuzzy binomial model parameters

\begin{tabular}{|c|c|c|c|c|}
\hline Up - Down & & $\mathrm{u}^{\prime}$ & & $\mathrm{d}^{\prime}$ \\
\hline Pessimist & $\mathrm{u}^{\prime} 1$ & 1.290461621 & $\mathrm{~d}^{\prime} 1$ & 0.774916498 \\
\hline Base & $u^{\prime} 2$ & 1.349858808 & $\mathrm{~d}^{\prime} 2$ & 0.740818221 \\
\hline Optimist & $u^{\prime} 3$ & 1.41198992 & $d^{\prime} 3$ & 0.708220353 \\
\hline Fuzzy Certain Equivalents & & $\mathrm{p}^{\prime}$ & & $1-\mathrm{p}^{\prime}$ \\
\hline Pessimist & $\mathrm{p}^{\prime} 1$ & 0.456087467 & $1-p^{\prime} 1$ & 0.543912533 \\
\hline Base & $p^{\prime} 2$ & 0.442059121 & $1-p^{\prime} 2$ & 0.557940879 \\
\hline Optimist & $p^{\prime} 3$ & 0.428875911 & 1-p'3 & 0.571124089 \\
\hline Coefficient Combinations & & $\mathrm{p}^{\prime}$ & & $1-\mathrm{p}^{\prime}$ \\
\hline Pessimist & p'3 & 0.428875911 & $1-p^{\prime} 1$ & 0.543912533 \\
\hline Base & $p^{\prime} 2$ & 0.442059121 & $1-p^{\prime} 2$ & 0.557940879 \\
\hline Optimist & $\mathrm{p}^{\prime} 1$ & 0.456087467 & $1-p^{\prime} 3$ & 0.571124089 \\
\hline
\end{tabular}

Source: Own elaboration.

On this previous grill, only fuzzy nodes $(\mathrm{t}=3)$ consider the possibility of firm liquidation as long as debt is higher than total firm value. The model assumes firm's equity $\left(E^{\prime}\right)$ as an adjusting variable. Therefore, it is the base to project the grill which considers contingent estates of solvency-insolvency in intermediate, final nodes, and consequently, in project value.

c) Conditioned $\left(E^{*}\right),\left(D^{*}\right),\left(F^{*}\right)$ binomial grill projection: From binomial grills from Tables 6 and 7 , we project conditioned values to states of solvency (continuity) - insolvency (liquidation) for fuzzy nodes. In order to do this, we use the following set of equations (a) final nodes ( $\mathrm{t}=\mathrm{T})$ (equations 24 to 29); (b) intermediate nodes $(T<t ; t>0)$ (equations 30 to 35); (c) present value initial node $(t=1 \rightarrow 0)$ (equations 36 to 38 ). 


\section{1) Macrothink}

Table 6. Fuzzy binomial grill. $V^{\prime}$ (firm value without debt); $\delta^{\prime}$ (free cash flow after taxes); $C^{\prime}$ (debt cash flow before taxes)

\begin{tabular}{|c|c|c|c|c|c|c|c|c|}
\hline & & & & & & & 3 & \\
\hline \multirow[t]{36}{*}{$\$$} & 455.40 & $\$$ & 587.68 & $\$$ & 758.38 & $\$$ & 978.66 & V \\
\hline & & $\$$ & 614.73 & $\$$ & 829.80 & $\$$ & 1.120 .11 & $V$ \\
\hline & & $\$$ & 643.03 & $\$$ & 907.95 & $\$$ & 1.282 .01 & V \\
\hline & & $\$$ & 30.13 & $\$$ & 38.88 & $\$$ & 50.18 & $\delta$ \\
\hline & & $\$$ & 31.52 & $\$$ & 42.54 & $\$$ & 57.43 & $\delta$ \\
\hline & & $\$$ & 32.97 & $\$$ & 46.55 & $\$$ & 65.73 & $\delta$ \\
\hline & & $\$$ & 20.72 & $\$$ & 20.72 & $\$$ & 20.72 & $C$ \\
\hline & & $\$$ & 15.94 & $\$$ & 15.94 & $\$$ & 15.94 & $C$ \\
\hline & & $\$$ & 11.16 & $\$$ & 11.16 & $\$$ & 11.16 & $C$ \\
\hline & & $\$$ & 352.90 & $\$$ & 455.40 & $\$$ & 587.68 & $V$ \\
\hline & & $\$$ & 337.37 & $\$$ & 455.40 & $\$$ & 614.73 & $V$ \\
\hline & & $\$$ & 322.53 & $\$$ & 455.40 & $\$$ & 643.03 & $V$ \\
\hline & & $\$$ & 18.09 & $\$$ & 23.35 & $\$$ & 30.13 & $\delta$ \\
\hline & & $\$$ & 17.30 & $\$$ & 23.35 & $\$$ & 31.52 & $\delta$ \\
\hline & & $\$$ & 16.54 & $\$$ & 23.35 & $\$$ & 32.97 & $\delta$ \\
\hline & & $\$$ & 20.72 & $\$$ & 20.72 & $\$$ & 20.72 & $C$ \\
\hline & & $\$$ & 15.94 & $\$$ & 15.94 & $\$$ & 15.94 & $C$ \\
\hline & & $\$$ & 11.16 & $\$$ & 11.16 & $\$$ & 11.16 & $C$ \\
\hline & & & & $\$$ & 273.47 & $\$$ & 352.90 & $V$ \\
\hline & & & & $\$$ & 249.93 & $\$$ & 337.37 & V \\
\hline & & & & $\$$ & 228.42 & $\$$ & 322.53 & $V$ \\
\hline & & & & $\$$ & 14.02 & $\$$ & 18.09 & $\delta$ \\
\hline & & & & $\$$ & 12.81 & $\$$ & 17.30 & $\delta$ \\
\hline & & & & $\$$ & 11.71 & $\$$ & 16.54 & $\delta$ \\
\hline & & & & $\$$ & 20.72 & $\$$ & 20.72 & $C$ \\
\hline & & & & $\$$ & 15.94 & $\$$ & 15.94 & $C$ \\
\hline & & & & $\$$ & 11.16 & $\$$ & 11.16 & C \\
\hline & & & & & & $\$$ & 211.91 & $V$ \\
\hline & & & & & & $\$$ & 185.15 & $V$ \\
\hline & & & & & & $\$$ & 161.77 & $V$ \\
\hline & & & & & & $\$$ & 10.87 & $\delta$ \\
\hline & & & & & & $\$$ & 9.49 & $\delta$ \\
\hline & & & & & & $\$$ & 8.29 & $\delta$ \\
\hline & & & & & & $\$$ & 20.72 & $C$ \\
\hline & & & & & & $\$$ & 15.94 & $C$ \\
\hline & & & & & & $\$$ & 11.16 & $C$ \\
\hline
\end{tabular}

Source: Own elaboration. 
Table 7. Binomial grill without conditioning intermediate nodes: $E^{\prime}$ (shareholders' equity); $D^{\prime}$ (debt value); $F^{\prime}$ (leveraged firm value)

\begin{tabular}{|c|c|c|c|c|c|c|c|c|}
\hline \multicolumn{2}{|c|}{0} & \multicolumn{2}{|c|}{1} & \multicolumn{2}{|c|}{2} & \multicolumn{3}{|c|}{3} \\
\hline$\$$ & 129.80 & $\$$ & 241.96 & $\$$ & 427.63 & $\$$ & 696.59 & \\
\hline$\$$ & 156.65 & $\$$ & 292.83 & $\$$ & 519.82 & $\$$ & 848.40 & $E$ \\
\hline$\$$ & 190.00 & $\$$ & 353.97 & $\$$ & 627.08 & $\$$ & 1.021 .70 & \\
\hline$\$$ & 245.06 & $\$$ & 284.95 & $\$$ & 311.03 & $\$$ & 339.50 & \\
\hline$\$$ & 258.98 & $\$$ & 296.87 & $\$$ & 315.23 & $\$$ & 334.72 & $D$ \\
\hline$\$$ & 273.56 & $\$$ & 308.77 & $\$$ & 319.18 & $\$$ & 329.94 & \\
\hline$\$$ & 374.87 & $\$$ & 526.91 & $\$$ & 738.66 & $\$$ & 1.036 .09 & \\
\hline$\$$ & 415.63 & $\$$ & 589.70 & $\$$ & 835.05 & $\$$ & 1.183 .12 & $F$ \\
\hline$\$$ & 463.57 & $\$$ & 662.74 & $\$$ & 946.26 & $\$$ & 1.351 .64 & \\
\hline & & $\$$ & 62.62 & $\$$ & 135.18 & $\$$ & 285.56 & \\
\hline & & $\$$ & 66.13 & $\$$ & 145.43 & $\$$ & 317.11 & $E$ \\
\hline & & $\$$ & 70.58 & $\$$ & 157.32 & $\$$ & 349.96 & \\
\hline & & $\$$ & 253.74 & $\$$ & 311.03 & $\$$ & 339.50 & \\
\hline & & $\$$ & 257.66 & $\$$ & 315.23 & $\$$ & 334.72 & $D$ \\
\hline & & $\$$ & 262.03 & $\$$ & 319.18 & $\$$ & 329.94 & \\
\hline & & $\$$ & 316.35 & $\$$ & 446.22 & $\$$ & 625.06 & \\
\hline & & $\$$ & 323.79 & $\$$ & 460.66 & $\$$ & 651.83 & $F$ \\
\hline & & $\$$ & 332.61 & $\$$ & 476.50 & $\$$ & 679.90 & \\
\hline & & & & $\$$ & 15.65 & $\$$ & 38.74 & \\
\hline & & & & $\$$ & 10.63 & $\$$ & 25.53 & $E$ \\
\hline & & & & $\$$ & 5.60 & $\$$ & 13.03 & \\
\hline & & & & $\$$ & 250.10 & $\$$ & 339.50 & \\
\hline & & & & $\$$ & 240.60 & $\$$ & 334.72 & $D$ \\
\hline & & & & $\$$ & 232.28 & $\$$ & 329.94 & \\
\hline & & & & $\$$ & 265.75 & $\$$ & 378.25 & \\
\hline & & & & $\$$ & 251.23 & $\$$ & 360.25 & $F$ \\
\hline & & & & $\$$ & 237.87 & $\$$ & 342.97 & \\
\hline & & & & & & $\$$ & - & \\
\hline & & & & & & $\$$ & - & $E$ \\
\hline & & & & & & $\$$ & - & \\
\hline & & & & & & $\$$ & 220.55 & \\
\hline & & & & & & $\$$ & 192.70 & $D$ \\
\hline & & & & & & $\$$ & 168.36 & \\
\hline & & & & & & $\$$ & 220.55 & \\
\hline & & & & & & $\$$ & 192.70 & $F$ \\
\hline & & & & & & $\$$ & 168.36 & \\
\hline
\end{tabular}

Source: Own elaboration. 


\section{Macrothink}

Table 8. Conditioned fuzzy binomial grill on intermediate nodes E' (equity value); D' (debt value); F' (leveraged firm value)

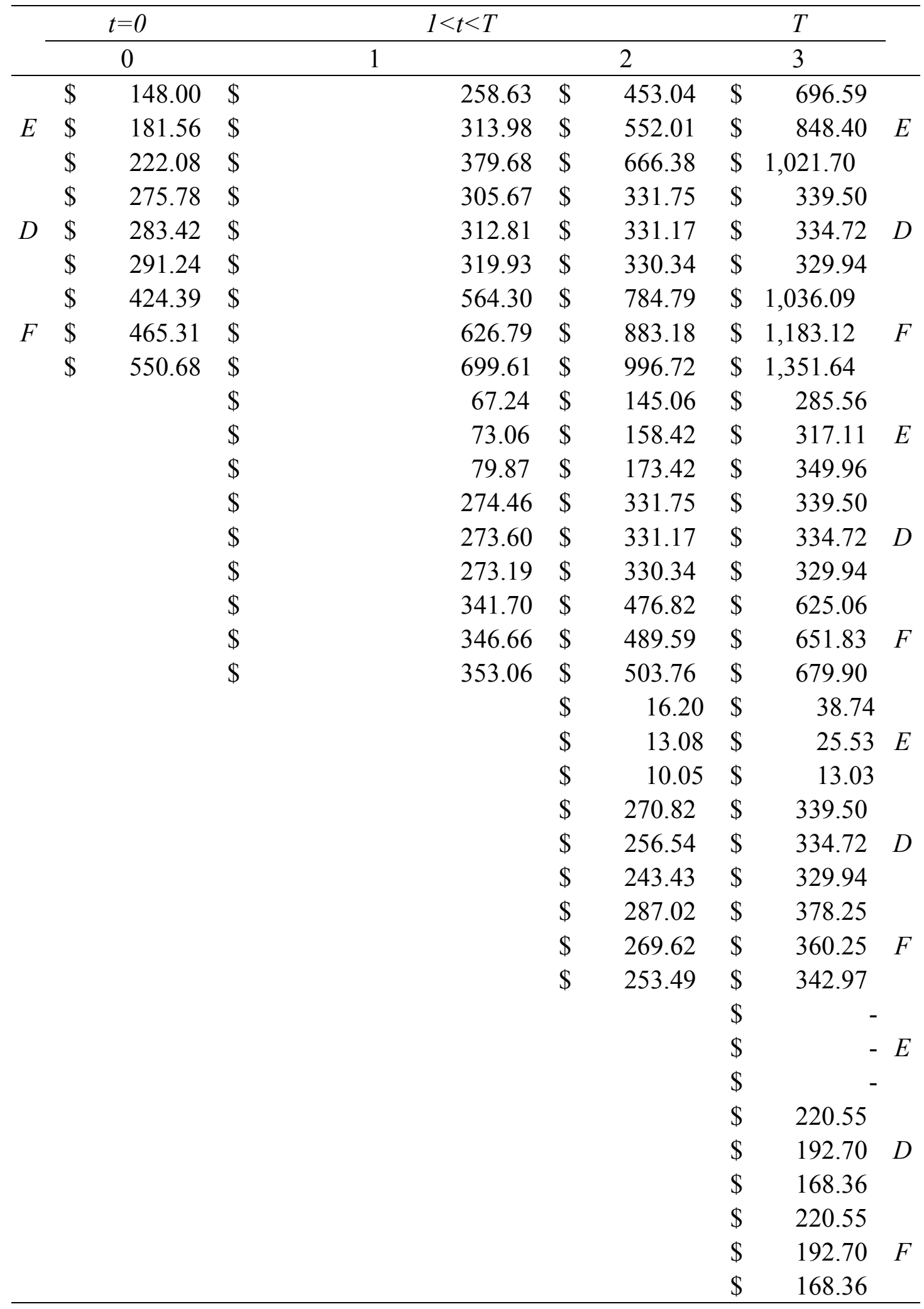

Source: Own elaboration. 
In $\mathrm{t}=0$, we obtain fuzzy values associated to firm value (F'), debt (D') and shareholders' equity (E') which resumes possible fuzzy values as a result of volatility and interest rate variability conditioned by the solvency-insolvency states. The fuzzy expected mean present value (equations $14,15,16$ ) reveals the following results:

Table 9. Fuzzy expected present value E'(equity value), D' (debt value), F' (leveraged firm value)

\begin{tabular}{|c|c|c|c|c|c|c|c|c|}
\hline Values & & $C 1$ & & $C 2$ & & C3 & & $E M V$ \\
\hline$E^{\prime}$ & $\$$ & 148.00 & $\$$ & 181.56 & $\$$ & 222.08 & $\$$ & 189.82 \\
\hline$D^{\prime}$ & $\$$ & 275.78 & $\$$ & 283.42 & $\$$ & 291.24 & $\$$ & 284.83 \\
\hline$F^{\prime}$ & $\$$ & 424.39 & $\$$ & 465.31 & $\$$ & 550.68 & $\$$ & 487.54 \\
\hline$\lambda / 1-\lambda$ & & 0.32401 & \multicolumn{6}{|c|}{0.67599} \\
\hline
\end{tabular}

Source: Own elaboration.

Next, we will present firm values obtained through adjusted present value (equation 39), traditional binomial, and fuzzy binomial.

Table 10. Firm value (V), adjusted present value, binomial, fuzzy binomial

\begin{tabular}{|c|c|c|c|c|c|c|c|c|}
\hline Model & & $V$ & & $P V$ & & $B$ & & $B$ \\
\hline Binomial (B) & $\$$ & 465.31 & $\$$ & 101.67 & & - & $\$$ & 22.23 \\
\hline Fuzzy Binomial (FB) & $\$$ & 487.54 & $\$$ & 79.44 & $\$$ & -22.23 & $\$$ & -79.44 \\
\hline Adjusted Present Value (APV) & $\$$ & 566.98 & & - & $\$$ & -101.67 & & - \\
\hline
\end{tabular}

Source: Own elaboration.

If we determine firm value with the adjusted present value (APV) method (equation 39), it rises to $\$ 566.98$ millions. This is a result of adding firm value without debt, unconditioned to scenarios of solvency-insolvency (Vu); $\$ 455.40$ millions, and effects of debt (ED), \$111.57 millions. The \$101.67-million difference between APV and binomial, and the \$79.44-million difference between APV and fuzzy binomial occurs because binomial models capture negative impact on firm value of the probability of liquidation as a result of insufficient cash flow to pay debt. This contingent state is not assumed by the APV. The difference between the fuzzy binomial model and the traditional binomial model is $\$ 22.23$ millions, higher for the first one. This is because of the positive bias associated to the defined TFN being $\lambda$ equal to 0.6759 according to Table 9 .

\section{Conclusions}

Throughout this paper, we propose a binomial fuzzy model which is compared with both traditional binomial and DCF models. We also highlight advantages and differences among them.

This model is highly useful to study the impact of financial decisions on firm value on contingent situations of solvency-insolvency that condition firm continuity or liquidation. It 
does not abandon the classical concept of equalizing firm equity to a financial call which exercise price are its liabilities, and the underlying asset is the total value of operating assets. This preceding idea is adapted to a dynamic numerical model in discrete time using fuzzy binomial grills. They allow to project different nodes (states) with two triangular fuzzy variables conditioning firm continuity or liquidation in cash flow generation after taxes. This mentioned cash flow is used to attend debt payments affecting firm value estimation and shareholders' equity. As a result, obtained project value and, consequently, its capital structure resume a set of projected contingent states in ambiguity situations considering firm continuity or liquidation. Frequently, insolvency risks and firm liquidation are not contemplated since the used cost of capital rates assume that firms are already operating. Therefore, they could not be applied to valuate contingent situations opening a niche to alternative decisions such as expansion, liquidation, abandonment, deferment.

Our presented, developed, and exemplified model contemplates the DCF and the traditional binomial real option model as well. This is because the DCF assumes decisions irreversibility and operating firm situation. The traditional binomial model weakens previous restrictions incorporating strategic decision values. However, it has a limitation of not incorporating ambiguous variables in the analysis. Thus, fuzzy logic applied to option models complements the probabilistic valuation in a possibilities setting.

Our proposed model also enhances scenarios' technique and simulation allowing us to capture positive bias in the investment possible values distribution. This is a characteristic of real options contained in the asset. It is reflected on our developed case where fuzzy binomial model results in mathematically higher value than the traditional binomial value because of the positive bias associated to TFN.

\section{References}

Berger, A., \& Udell, G. (1998). The economics of small business finance: The roles of private equity and debt market in financial growth cycles. Journal of Banking and Finance, 22, 613-673. http://dx.doi.org/10.1016/s0378-4266(98)00038-7

Black, F., \& Scholes, M. (1972). The Valuation of Options Contracts and a Test of Market Efficiency. Journal of Finance, 27(2), 399-418. http://dx.doi.org/10.2307/2978484

Black, F., \& Scholes, M. (1973). The Pricing of Options and Corporate Liabilities. Journal of Political Economy, 81(3), 637-659. http://dx.doi.org/10.1086/260062

Booth, L. (2007). Capital Cash Flow, APV and Valuation. European Financial Management, 13(1), 29-48. http://dx.doi.org/10.1111/j.1468-036x.2006.00284.x

Brander, J., \& Lewis T. (1986). Oligopoly and financial structure: The limited liability effect. American Economics Review, 76(5), 956-970.

Broadie, M., \& Kaya, O. (2007). A Binomial Lattice Method for Pricing Corporate Debt and Modelling Chapter 11 Procedings. Journal of Finance and Quantitative Analysis, 42(2), 
279-312. http://dx.doi.org/10.1017/s0022109000003288

Calle Fernández, A., \& Tamayo Bustamante, V. (2011). Decisiones de inversión a través de opciones reales. Estudios Gerenciales, 25(111), 107-126. http://dx.doi.org/10.1016/s0123-5923(09)70073-7

Carlsson, C., \& Fuller, R. (2001). On possibilistic mean value and variance fuzzy numbers. $\begin{array}{llll}\text { Fuzzy Sets and } & \text { 315-326. }\end{array}$ http://dx.doi.org/10.1016/s0165-0114(00)00043-9

Copeland, T., \& Antikarov, V. (2001). Real options (1st ed.). New York: Texere LLC.

Copeland, T., \& Tufano, P. (2004). A real world to manage real options. Harvard Business School Review, 82, 90-99.

Copeland, T., Weston, F., \& Shastri, K. (2004). Financial theory and corporate policy (4th ed.). United States: Pearson Addison Wesley.

Cox, J., Ross, S., \& Rubinstein, M. (1979). Option pricing: A simplified approach. Journal of Financial Economics, 7(3), 229-263. http://dx.doi.org/10.1016/0304-405x(79)90015-1

Cox, J., \& Ross, S. (1976). The valuation of options for alternative stochastic processes. Journal of Financial Economics, 3(1-2), $\quad$ 145-166. http://dx.doi.org/10.1016/0304-405x(76)90023-4

Dubois, D., \& Prade, H. (1980). Fuzzy sets and systems. New York: Academic Press.

Duran, D. (1957). Growth stock and the Petersburg paradox. Journal of Finance, 12(3), 348-363. http://dx.doi.org/10.1111/j.1540-6261.1957.tb04143.x

Fernández, P. (2012). Valuing companies by cash flow discounting: Fundamental ideas and unnecessary complications (April 28, 2014). http://dx.doi.org/10.2139/ssrn.2089397

Fornero, R. (2011). Las prácticas en las decisiones de inversión: Sus características según los estudios empíricos. XXX Jornadas Nacionales de Docentes en Administración Financiera SADAF, 30, 83-165.

Gordon, M. J. (1962). The Investment, Financing and Valuation of the Corporation. Illinois: Irwin Homewood. http://dx.doi.org/10.1086/294541

Hurley, W. (2013). Calculating first moments and confidence intervals for generalized stochastic dividend discount models. Journal of Mathematical Finance, 3, 275-279. http://dx.doi.org/10.4236/jmf.2013.32027

Hurley, W., \& Fabozzi, F. (1998). Selected topics in equity portfolio management (1st ed.). Pennsylvania: New Hope.

Hurley, W., \& Johnson, L. (1998). Generalized Markov dividend discount models. Journal of Portfolio Management, 25(1), 27-31. http://dx.doi.org/10.3905/jpm.1998.409658

Jarrow, R-Rudd, A. (1982). Aproximate option valuation for arbitrary stochastic processes. 
$\begin{array}{llll}\text { Journal of Financial } & \text { Economics, } & \text { 10(3), } & \text { 347-369. }\end{array}$ http://dx.doi.org/10.1016/0304-405x(82)90007-1

Jensen, M. (1986). Agency costs of the free cash flow, corporate finance and takeover. American Economic Review Paper and Proccedings, 76(2), 323-329. http://dx.doi.org/10.1017/cbo9780511609435.005

Jensen, M., \& Meckilng, W. (1976). Theory of the firm: Managerial behavior, agency costs and ownership structure. Journal of Financial Economics, 305-360. http://dx.doi.org/10.1016/0304-405x(76)90026-x

Leland, H., \& Pyle D. (1977). Informational asymmetries, financial structure and financial intermediation. Journal of Finance, 32(2), 371-387. http://dx.doi.org/10.2307/2326770

Liao, S., \& Ho, S. (2010). Investment project valuation based on a fuzzy bionomial approach. Information Sciences, 180(11), 2124-2133. http://dx.doi.org/10.1016/j.ins.2010.02.012

Milanesi, G. (2013). El modelo binomial borroso y la valuación de opciones reales: El caso de valuación de un contrato de conseción para la explotación petrolera. Estocástica: Finanzas y Riesgo, 3(2), 95-118.

Milanesi, G. (2014). Modelo binomial para la valoración de empresas y los efectos de la deuda: Escudo fiscal y liquidación de la firma. Journal of Economics, Finance and Administrative Science, 19(36), 2-10. http://dx.doi.org/10.1016/j.jefas.2014.03.004

Milanesi, G. (2014). Valoración probabilística versus borrosa, opciones reales y el modelo binomial: Aplicación para proyectos de inversión en condiciones de ambigüedad. Estudios Gerenciales, 30(132), 211-219. http://dx.doi.org/10.1016/j.estger.2014.01.018

Modigliani, F., \& Miller, M. (1958). The cost of capital, corporation finance and the theory of investment. American Economic Review, 261-297. http://dx.doi.org/10.1080/17446540802345448

Modigliani, F., \& Miller M. (1963). Corporate taxes and cost of capital. American Economic Review, 433-443.

Muzzioli, S., \& Torricelli, A. (2004). A multiperiod binomial model for pricing options in a vague world. Journal of Economics and Dynamics Control, 28(5), 861-867. http://dx.doi.org/10.1016/s0165-1889(03)00060-5

Myers, S., \& Majluf, N. (1984). Corporate financing and investment decisions when firms have informarion that investors do not have. Journal of Financial Economics, 13(2), 187-221. http://dx.doi.org/10.1016/0304-405x(84)90023-0

Pratt; S., \& Grabowski; R. (2008). Cost of capital: Applications and examples (3rd ed.). New Jersey: John Wiley \& Sons. http://dx.doi.org/10.1002/9781118846780

Rendleman, R., \& Bartter, B. (1979). Two-state option pricing. Journal of Finance, 34(5), 1093-1110. http://dx.doi.org/10.1111/j.1540-6261.1979.tb00058.x 
Ross, S. (1977). The determination of financial structure: The incentive of signalling approach. Bell Journal of Economics, 8(1), 23-40. http://dx.doi.org/10.2307/3003485

Rubinstein, M. (1973). A mean-variance synthesis of corporate financial theory. Journal of Finance, 28(1), 167-181. http://dx.doi.org/10.1111/j.1540-6261.1973.tb01356.x

Smith, J. (2005). Alternative approach for solving real options problems. Decision Analysis, 2(2), 89-102. http://dx.doi.org/10.1287/deca.1050.0041

Stiglitz, J., \& Weiss, A. (1981). Credit rationing in markets with imperfect information. American Economics Review, 71(3), 393-409. http://dx.doi.org/10.2139/ssrn.1010965

Titman, S. (1984). The effects of capital structure on a firm's liquidation decisions. Journal of Financial Economics, $\quad 13(1), \quad 137-151$. http://dx.doi.org/10.1016/0304-405x(84)90035-7

Wang, A., \& Halal, W. (2010). Comparision of real asset valuation models: A literature review. International Journal of Business and Management, 5(5), 14-24. http://dx.doi.org/10.5539/ijbm.v5n5p14

Williams, J. B. (1938). Theory of investment. New York: Fraser Publishing Company.

Wilmott, P. (2009). Frequently asked questions in quantitative finance (2nd ed.). United Kingdom: John Wiley \& Sons.

Yoshida, Y., Yasuda, M., Nakagami, J., \& Kurano, M. (2006). A new evaluation of mean value for fuzzy numbers and its application to american options under uncertainty. Fuzzy Sets and Systems, 157(19), 2614-2626. http://dx.doi.org/10.1016/j.fss.2003.11.022

Zadeh, L. (1965). Fuzzy sets. Information Control, 8(3), 338-353. http://dx.doi.org/10.1016/s0019-9958(65)90241-x

Zdnek, Z. (2010). Generalised soft binomial american real option pricing model. European Journal of Operational Research, 207(2), 1096-1103. http://dx.doi.org/10.1016/j.ejor.2010.05.045

\section{Copyright Disclaimer}

Copyright for this article is retained by the author(s), with first publication rights granted to the journal.

This is an open-access article distributed under the terms and conditions of the Creative Commons Attribution license (http://creativecommons.org/licenses/by/3.0/). 